\title{
Editorial
}

\section{Human Rights, Comparative Law and Global Governance}

This special issue focuses on human rights viewed from two perspectives: comparative methodology and global governance. It contains two comparative studies arising from long-term research projects. The first study, authored by Lottie Lane, deals with human rights and non-State actors. It starts from the premise that in the contemporary world, States are continuously losing ground to private actors. Many non-State actors - for example, multinational corporations and non-State armed groups - are in a position to greatly affect individuals' enjoyment of their human rights. The article critically analyses how and to what extent international human rights have had some kind of horizontal effect on non-State actors in the general comments and jurisprudence of five United Nations human rights treaty monitoring bodies. ${ }^{1}$ It compares the different ways in which the five monitoring bodies deal with situations and cases where the harm to an individual's human rights was directly caused by a non-State actor. The study comes to the conclusion that currently, the horizontal effect of human rights at the international level is only indirect: non-State actors still do not have any binding international law obligations concerning human rights. However, on many occasions, the interpretations and applications of United Nations human rights treaties by the monitoring bodies have clearly acknowledged the fact that situations of human rights violations can be caused by actions of private actors as well as States. In some occasions the

1 The five bodies are: (1) the Human Rights Committee; (2) the Committee on Economic, Social and Cultural Rights; (3) the Committee on the Elimination of Discrimination against Women; (4) the Committee against Torture; and (5) the Committee on the Elimination of all Forms of Racial Discrimination.

(C) CIACCHI, 2018 | DOI 10.1163/22134514-00501003

This is an open access article distributed under the terms of the prevailing CC-BY-NC license at the time of publication. 
monitoring bodies have explicitly acknowledged a more significant and perhaps even positive role for non-State actors within international human rights law. Lane identifies two types of indirect horizontal effect in the general comments and jurisprudence of the five monitoring bodies. The first type, called by her 'pure' indirect horizontal effect, consists in the application of States' positive obligation to protect human rights from the harmful actions of non-State actors. This generally corresponds to an obligation of due diligence, including a specific obligation to regulate the conduct of non-State actors at the national level, in order to prevent, investigate, punish and provide redress for human rights violations caused by non-State actors. The second type is called by Lane 'categorical' indirect horizontal effect, since it implies the re-categorisation of some non-State actors as public actors for the purposes of a specific situation. It concerns non-State actors carrying out particular public functions normally undertaken by the State and having effective control over a certain area of territory. This second type of horizontal effect provides extra protection for individuals in situations where the State may fulfil its obligation of conduct under the obligation to protect, but remains in a position where it is unable to provide de facto protection. So far, the categorical indirect horizontal effect has only been applied in relation to non-State armed groups.

Lane's article forms part of a more comprehensive, long-term research project, which in its last phase crosses the boundary between law and governance and includes a multi-level governance analysis of possible (extra-legal) remedies against non-State actors' interferences with individuals' human rights. The present article, however, arises from the first phase of this project and concentrates much more on the law than on the governance. The opposite is true for the second contribution included in this issue, which concentrates much more on the governance than on the law: Monaco's article dealing with human rights indicators as a specific 'technology of global governance.' ${ }^{2}$

Also Monaco's study originates from a more comprehensive research project: HEURIGHT - The Right to Cultural Heritage Project', involving several researchers from Poland, the UK and Italy. The aim of the project is to investigate how human rights guarantees in relation to cultural heritage are being understood and implemented in the EU and in its neighbouring countries. ${ }^{3}$ Monaco's research within this project focuses on the Western Balkan countries Bosnia and Herzegovina, Croatia, Serbia, and Montenegro. Her article offers a comparative review of two global initiatives that recently published

2 K. Davis et al., 'Indicators as a Technology of Global Governance', Law and Society Review 46(1) (2012) 81.

3 See the project's website: www.heuright.eu/. 
indicators on culture, sustainable development and tourism: the Culture for Development Indicators (CDIS), drafted by the UNESCO; and the Sustainable Tourism Indicators, published by the United Nations World Tourism Organization (UNWTO).

Monaco's comparative study comes to the conclusion that global indicators drafted by international organisations are powerful soft-law instruments to ensure the enforcement of hard-law international obligations. The main contribution of such indicators is to raise States' awareness about the links between culture, development, and tourism, and to provide precious data for the global debate in this regard. Indicators are powerful governance instruments "because they bypass traditional law-making processes, and rather subtly convey mind-sets, priorities and policies that are more or less spontaneously internalised by their targets". ${ }^{4}$ The transformative power of this technology of global governance "operates not only within the circle of the actors who participate in collecting statistics and preparing the indicators, that is, the target-states, but also in providing a platform where other actors - civil society, minorities, non-governmental organisations - can transact and communicate through the common language of statistics and data."

Monaco's article does not only highlight the positive, but also the problematic aspects of such global indicators. She acknowledges that "(b)y shedding light on given problems, themes and priorities, indicators might also silence different issues that in principle might be equally worthy of attention. In other words, indicators might create the risk that whatever they do not cover gets lost or under-considered." ${ }^{6}$

Despite these shortcomings, Monaco evaluates the experience of the Western Balkan countries with the CDIS and UNWTO indicators as a positive one. "Through their involvement in the initiatives to prepare CDIS and UNWTO indicators, the Western Balkans countries have created a platform for dialogue between relevant stakeholders, and enhanced regional cooperation in the spheres of culture, development and tourism." 7

Monaco's comparative study deals with global governance instruments (indicators) concerning specific human rights: cultural rights, development rights, and the socio-economic rights concerned by the tourism industry. These

4 P. Monaco, 'Cultural Heritage, Development, Tourism, and Global Indicators: The Experience of Western Balkan Countries', in this issue, Section 5 .

5 Ibid., quoting among others Infantino, 'Human Rights Indicators across Institutional Regimes', International Organizations Law Review 12 (2015) 152-153.

6 Monaco, ibid.

7 Ibid. 
rights that have been labelled as pertaining to the second or third generation of human rights. ${ }^{8}$ Here Monaco's study can be linked to Lane's research. Lane agrees with the critiques formulated by a number of scholars ${ }^{9}$ against the categorization of human rights in different 'generations'. This metaphor should not be taken literally, since the generation of human rights do not succeed each other like the generations of human beings do. Second-generation and thirdgeneration human rights do not replace first-generation ones: the generations of human rights simply build on each other. The generations metaphor is only useful insofar it highlights the different historical periods in which different human rights were conceptualised..$^{10}$

To conclude: Lane's and Monaco's article taken together exemplify the contemporary research on human rights from a global governance perspective very well. Further contributions on human rights from a comparative law-andgovernance viewpoint are most welcome!

\section{Aurelia Colombi Ciacchi}

Editor-in-Chief EJCL; Professor of Law and Governance,

Academic Director Groningen Centre for Law and Governance,

University of Groningen, The Netherlands

a.l.b.colombi.ciacchi@rug.nl

8 The categorization of human rights in three generations goes back to K. Vasak, 'A 30 -Year Struggle', The UNEsco Collier 1977, 29. For a critical discussion thereon see P. Macklem, 'Human Rights in International Law: Three Generations or One?' 3 London Review of International Law 2015, 61.

9 P. Alston, 'A Third Generation of Solidarity Rights: Progressive Development or Obfuscation of International Human Rights Law?' (1982) 29(3) Netherlands International Law Review 307; C. Wellman, 'Solidarity, the Individual and Human Rights', 22(3) Human Rights Quarterly 2000, 639, 641.

10 L. Lane, The Horizontal Effect of International Human Rights - A Multi-Level Governance Approach, PhD thesis, Chapter 1 (on file with author). 